\title{
APYRENE SPERMATOZOA IN Achroia grisella (LEPIDOPTERA: PIRALIDAE): A HONEYBEE WAXMOTH
}

\author{
FERNANDEZ, F. C. and CRUZ-LANDIM, C. \\ Department of Biology, Institute of Biociences, Universidade Estadual Paulista - UNESP, \\ Av. 24A, C.P. 1515, CEP 13506-900, Rio Claro, SP, Brazil \\ Correspondence to: Carminda da Cruz-Landim, Department of Biology, Institute of Biociences, \\ Universidade Estadual Paulista -UNESP, Av. 24A, C.P. 1515, CEP 13506-900, Rio Claro, SP, Brazil, \\ e-mail: cclandim@rc.unesp.br
}

Received June 16, 2004 - Accepted November 30, 2004 - Distributed November 30, 2005

(With 4 figures)

Achroia grisella larvae are a well-known honeybee waxmoth recently found attacking stingless bees colonies (Cepeda-Aponte et al., 2002). As in other lepidopterans, two types of spermiogenesis occur in the cysts of the testis of $A$. grisella, one leading to the production of apyrene (enucleated) and the other to eupyrene (nucleated) sperm cells. The two types of cysts become recognizable only during spermiogenesis, for the early part of spermatogenesis appears to be the same in both sperm types. It is generally understood that most apyrene spermatozoa are produced later than eupyrene spermatozoa (Friedländer, 1997) but, in the $8^{\text {th }}$ larval instar of $A$. grisella, a few cysts containing apyrene spermatids are already present in the testis and eupyrene spermiogenesis still occurs in the young adult male. Apyrene spermatids are recognizable by the presence of a very irregular nucleus (Fig. 1) or by several micronuclei that result from nuclear fragmentation (Fig. 2). These micronuclei show scattered chromatin with some condensation in the nuclear periphery. Although the spermatid cytoplasm seems to remain whole, with a Golgi complex and a smooth endoplasmic reticulum, the nuclear changes it undergoes resemble cell death by apoptosis. Nevertheless, spermatozoa tail differentiation follows the normal pathway. All spermatic cell mitochondria gather around the nucleus and fuse together to form the structure known as the mitochondrial complex or Nebenkern (Fig. 3), from which the mitochondrial derivatives will differentiate, and the centriole gives rise to the $9+9+2$ flagellum. The anterior end of apyrene spermatozoa shows no nucleus, since this was lost during tail elongation. Instead, an electron-dense sheath covers the tail's anterior end. In a longitudinal section, the sheath has an inverted cup shape (Fig. 4). Therefore, the mature apyrene spermatozoa of A. grisella do not differ from the atypical spermatozoa of other lepidopterans with dimorphic spermatogenesis.

Although several hypotheses have been proposed (Friedänder, 1997; França \& Báo, 2000; Garvey et al., 2000; Mancini \& Dolder, 2004) to explain the event, the exact cause that determines the disappearance of the nucleus is still unknown. One possibility is that the hormonal changes that take place at the end of the larval stage and during pupation may influence spermiogenesis occurring late in the testis. However, as some apyrene cysts have been observed since the $8^{\text {th }}$ larval instar, when the hormone titers probably have not yet changed, other causes must work in combination with the hormonal balance. 


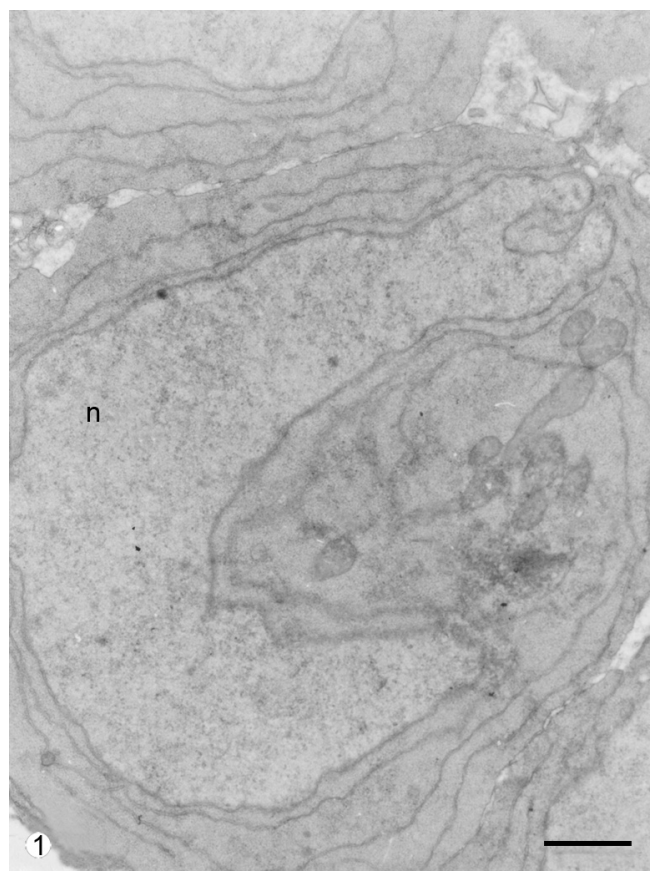

Fig. 1 - Apyrene spermatid showing a very irregular nucleus (n) with decondensed chromatin. Bar $=1.6 \mu \mathrm{m}$.

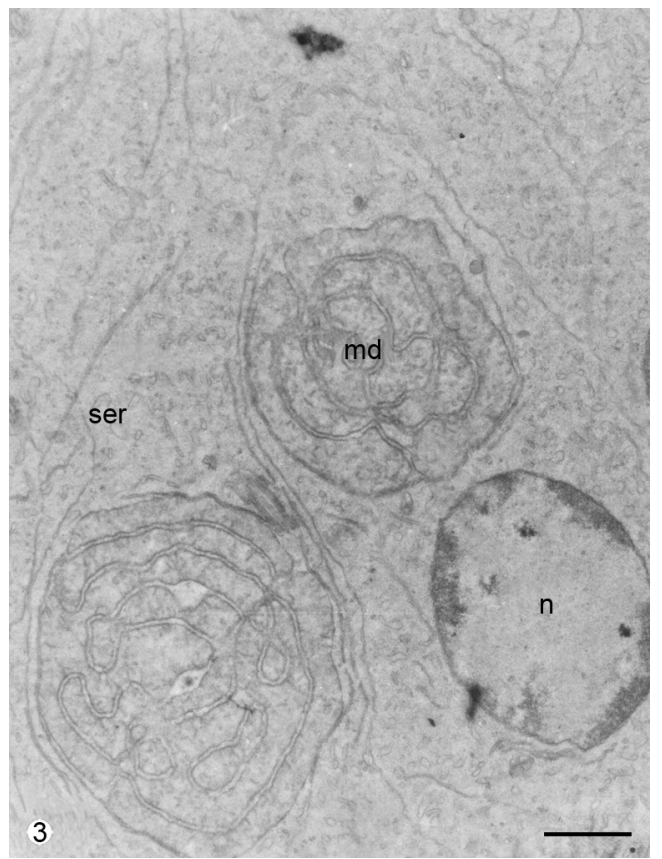

Fig. 3 - Correspondent eupyrene spermatid with a nucleus (n) beginning condensation. Bar $=2.0 \mu \mathrm{m}$. ser $=$ smooth endoplasmic reticulum; $\mathrm{md}=$ mitochondrial derivatives.

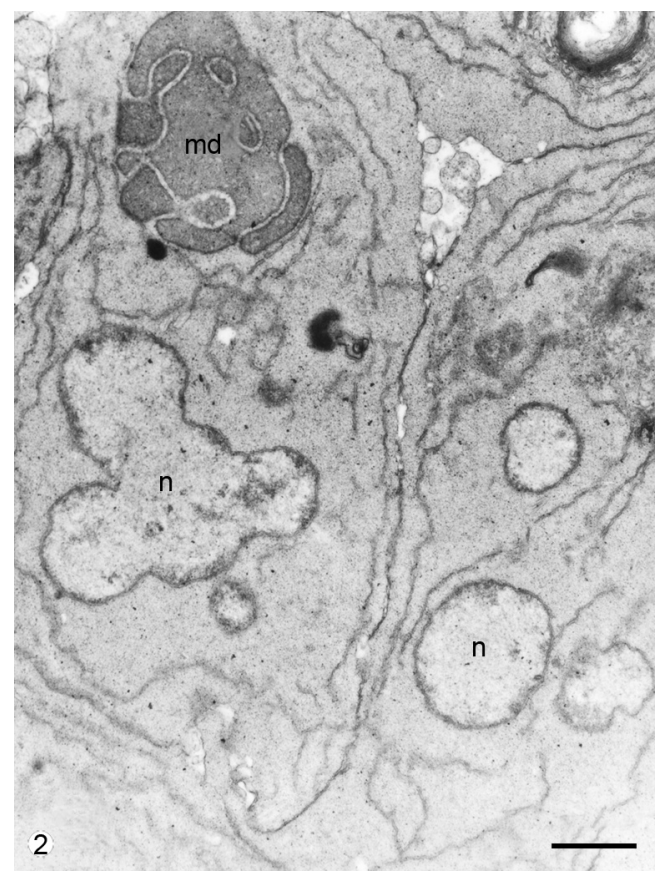

Fig. 2-A few late apyrene spermatids showing the bubbling nucleus (n) with chromatin condensation around the nuclear envelope. $\mathrm{md}=$ mitochondrial derivatives. $\mathrm{Bar}=1.6 \mu \mathrm{m}$.

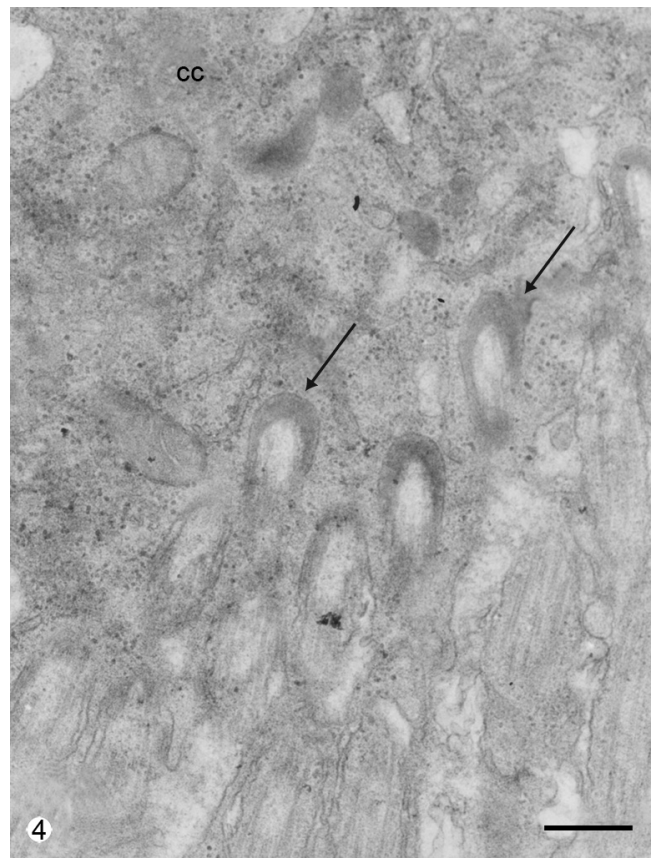

Fig. 4 - Immature apyrene spermatozoa with the tips enclosed in the cyst cell (cc). Note the presence of a sheath instead of a head (arrows). Bar $=1.6 \mu \mathrm{m}$. 


\section{REFERENCES}

CEPEDA-APONTE, O. I.; IMPERATRIZ-FONSECA, V. L. \& VELTHIUS, H. H. W., 2002, Lesser wax moth Achroia grisella: First report for stingless bees and new capture method. J. Apicultural Research, 51 (3-4):107-108.

FRANÇA, F.G.R. \& BÁO, S. N., 2000, Dimorphism in spermatozoa of Anticarsia gemmatalis Hüber, 1918 (Insecta, Lepidotera, Noctuidae). Braz. J. Morphol.Sci., 17: 5-10.
FRIEDLÄNDER, M., 1997, Control of the eupyrene-apyrene sperm dimorphism in Lepidoptera. J. Insect Physiol., 43: 1085-1092.

GARVEY, L. K.; GUTIERREZ, G. M. \& KRIDER, H. M., 2000, Ultrastructure and morphogenesis of the apyrene and eupyrene spermatozoa in the gypsy moth. Ann. Entomol. Soc. Am., 93: 1147-1155.

MANCINI, K. \& DOLDER H., 2004, Dichotomic spermatogenesis in Euptoieta hegesia (Lepidoptera, Nymphalidae). Braz. J. Morphol. Sci., 21(1): 13-23. 